\title{
Injection Site Reaction
}

National Cancer Institute

\section{Source}

National Cancer Institute. Injection Site Reaction. NCI Thesaurus. Code C3508.

An intense reaction (usually immunologic) developing at the site of injection 